\author{
초음파 진단장치를 이용한 한우 암소의 산차 및 지역별 산육특성 구명 \\ 하재정*· 김종복*·이창우**・ 송영한* \\ 강원대학교 동물자원과학대학*, 강원도 축산기술연구센터**
}

\title{
Studies on Live-carcass Trait of Parity and Region in Hanwoo Cows Measured by Real-time Ultrasound
}

\author{
Jae Jung Ha*, Jong Bok Kim*, Chang Woo Lee** and Young Han Song* \\ College of Animal Life Sciences, Kangwon National University*, \\ Research Center for Livestock Technology, Gangwon-do**
}

\begin{abstract}
Current study was conducted to investigate the influence of parity and region variation in ultrasound live carcass traits of Hanwoo cows. A total of 1,386 heads of Hanwoo cows, spreading over six regions in Gangwon province of South Korea, were measured for longissimus muscle area, back fat thickness, marbling score and rump fat thickness by using real-time ultrasound method. The results revealed that, positive correlations were found in all ultrasound live carcass traits. All live carcass traits were increased in accordance with parity until the sixth, and then decreased thereafter. Statistical significant differences $(p<0.01)$ were found among regions in ultrasound live carcass traits, e.g. Hanwoo cows showed highest longissimus muscle area and marbling score in Hwacheon, while the lowest back fat thickness and rump fat thickness were observed in Yanggu. Greater longissimus muscle area and marbling scores were found in Hanwoo cows which were born during autumn, 2000. Moreover, individuals born during autumn, 2005 and 2006 showed a thicker back fat and rump fat thickness. Back fat thickness had the highest positive correlation with rump fat thickness, while rib eye area and rump fat thickness had the lowest correlation.
\end{abstract}

(Key words: Hanwoo cows, Region, Parity, Ultrasound, Live carcass trait)

\section{I. 서 론}

개방화시대 경제성장과 더불어 삶의 질적 향상은 국민 의 식생활 개선에 많은 영향을 주어 안전한 고품질의 쇠 고기를 구입하고자 하는 소비자가 점차 증가하는 추세이 다. 계속되는 물가 상승은 사료가격 폭등으로 이어져 한 우를 생산하는데 소요되는 비용이 점차 증가하고 있으며, 수입육의 소비증가는 한우사육 농가를 더욱 위협하고 있 는 상황으로 중·장기적인 대응전략이 반드시 필요한 시 점으로 나타나게 되었다.

앞으로의 한우개량기술은 종모우뿐 아니라 번식우에도 초점을 맞춰야 한다. 생산비 중 가장 큰 비중으로는 밑소 구입비이며, 우량송아지의 생산은 밑소 판매시장에서의 높은 가격과 고급육 출현율 향상으로 농가의 수익을 증가 시켜 줄 것이다. 그러므로 한우산업에서 우량 송아지 생 산기반체계를 확립시키는 것이 무엇보다도 중요하다고 판 단된다.

한우의 개체별 능력은 부모로부터 물려받은 유전능력,
사양관리, 영양공급 및 환경 등의 다양한 요인들에 의해 영향을 받는다(권 등, 2006). 국내에서는 한우의 고급육 생 산을 위한 사양관리 개선 및 사료내 다양한 첨가제 등의 연구들이 꾸준히 진행되고 있으며, 최근에는 $\mathrm{DNA}$ 와 초음 파 진단장치를 이용하여 한우의 고급육 생산능력의 예측 이 활발히 이루어지고 있는 실정이다(배, 2003). 전 등 (2003)은 성장능력, 체조직 등의 상태를 파악하기 위한 자 료로서 환경적인 요인과 유전적 특성을 반드시 파악해야 한다는 보고와 같이 사양관리와 환경에 따른 산육특성 구 명에 관한 자료는 필수적이지만 아직 미미한 수준에 불과 하다.

따라서, 앞으로의 과제는 번식우 개량을 통한 고품질의 쇠고기 생산으로 소비자의 입맛을 사로잡아 쇠고기 유통 시장을 선점하여 한우산업의 지속적인 발전을 이끌어 나 가야 할 것이다.

이에 본 시험은 한우 번식우에 대하여 초음파 진단장치 를 이용한 산차 및 지역별 산육특성에 미치는 영향을 구 명함으로써, 번식우 개량에 대한 기초자료를 제시하고자

Corresponding author: Dr. Y. H. Song, College of Animal Life Sciences, Kangwon National University, Chuncheon 200-701, Korea. Tel: +82-33-250-8617, E-mail: yhsong@kangwon.ac.kr 
실시하였다.

\section{ㅍ. 재료 및 방법}

\section{1. 공시동물}

본 시험의 공시동물은 춘천, 철원, 화천, 양구, 인제, 횡 성의 한우 번식우 1,386 두를 이용하였다. 공시축의 출생년 도-계절, 산차 및 지역별 초음파 생체 단층 촬영두수 Table 1에 나타내었다.

2. 시험설계 및 사양관리

본 시험의 시험설계는 강원도 영서지역 6 개시·군을 대
상으로 출생년도-계절, 산차 및 지역별 한우암소의 차이 를 구명하였고, 농후사료 급여방식은 브랜드한우 사양관 리 프로그램에 따라 1일 2회 급여하였으며, 조사료 급여 는 건조볏짚을 급여하였다. 물과 mineral block은 자유롭게 섭취할 수 있도록 하였다.

\section{3. 성적조사 및 자료의 조정}

공시동물 중 산차별 분석에 이용된 두수는 미경산우를 제외한 1,080 두를 분석에 이용하였으며, 산육형질 중 배최 장근단면적 (LMAU) $30 \mathrm{~cm}^{2}$ 이하, 등지방두께 (BFTU) $12 \mathrm{~mm}$ 이상, 근내지방도 $(\mathrm{MSU})$ 6이상, 둔근지방두께 (P8 FTU) $18 \mathrm{~mm}$ 이상의 개체는 이상개체로 판단하여 산육특성에서 제외하였다.

Table 1. Number of animal by year-season, parity and region

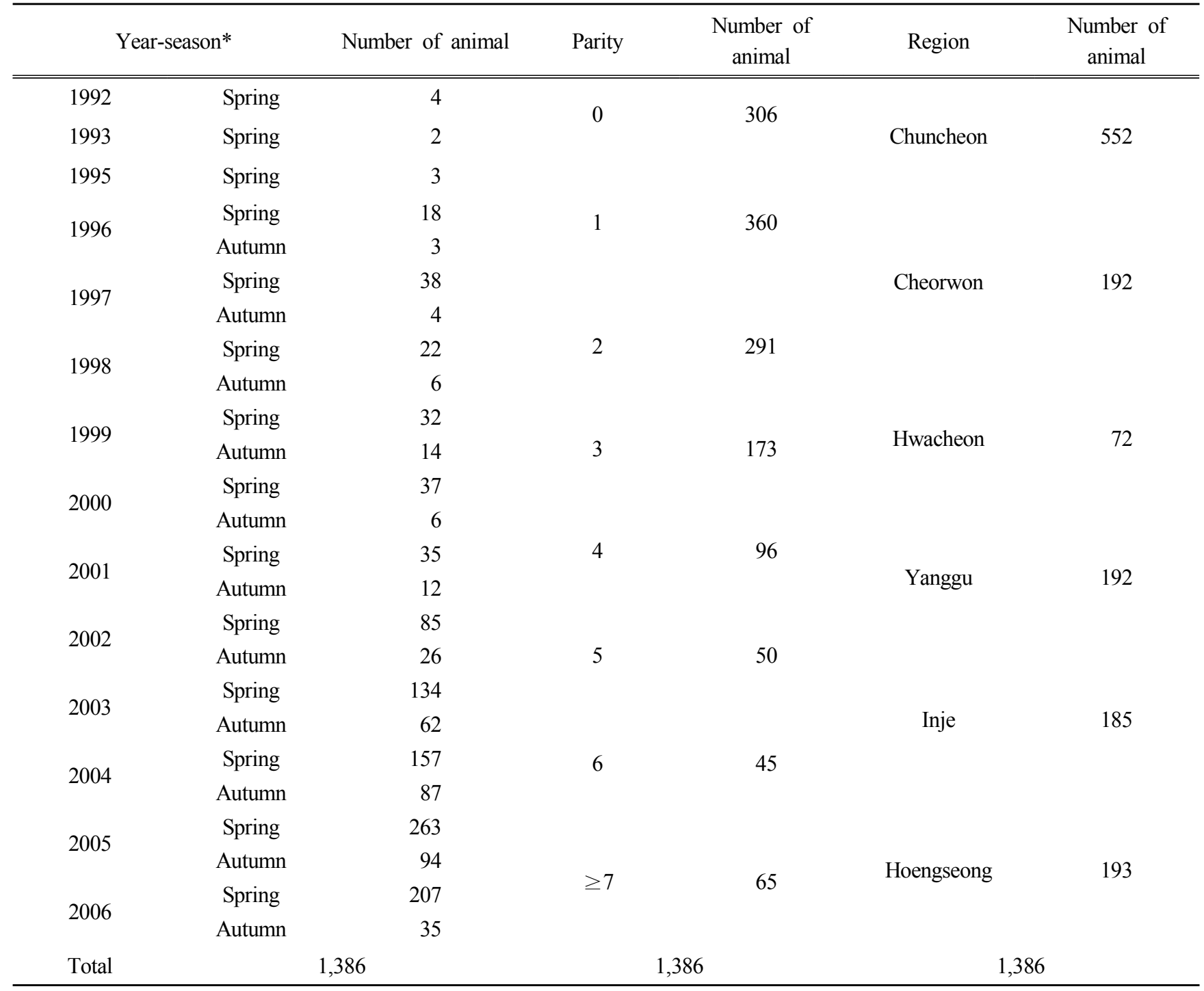

* Year-season : Birth year-season of cow 


\section{4. 초음파 측정시기 및 측정항목}

본 시험의 측정시기는 2007년 11월부터 2008년 7월까지 9개월간 실시하였으며, 출생년도-계절과 산차 및 지역별 로 구분하여 측정하였다.

측정항목으로는 실시간 초음파 진단장치(HS-2000; $2 \mathrm{MHz}$ linear probe; FHK, Japan)를 이용하여 현행 도체등급 판정 부위인 제 13 흉추와 제 1 요추 사이를 측정하여 초음파 배 최장근단면적(LMAU; Longissimus Muscle Area Ultrasound), 초음파 등지방두께(BFTU; Back Fat Thickness Ultrasound), 초음파 근내지방도(MSU; Marbling Score Ultrasound)를 측 정하였고 둔부(Rump)쪽을 이용하여 초음파 둔근지방두께 (P8 FTU; P8 Ultrasound Fat Thickness)를 측정하여 산육특 성을 비교하였으며, 조사된 형질들의 평균, 표준편차, 변 동계수, 최소·최대값은 Table 2와 같이 나타내었다.

\section{5. 통계분석}

시험에서 얻어진 모든 분석치들은 각 처리구별로 평균 치를 제시하였다. 분석치들의 유의성 검정은 Statistical Analysis System (SAS 9.1)을 프로그램을 이용하였으며, 분 석에 이용된 선형모형은 다음과 같다.

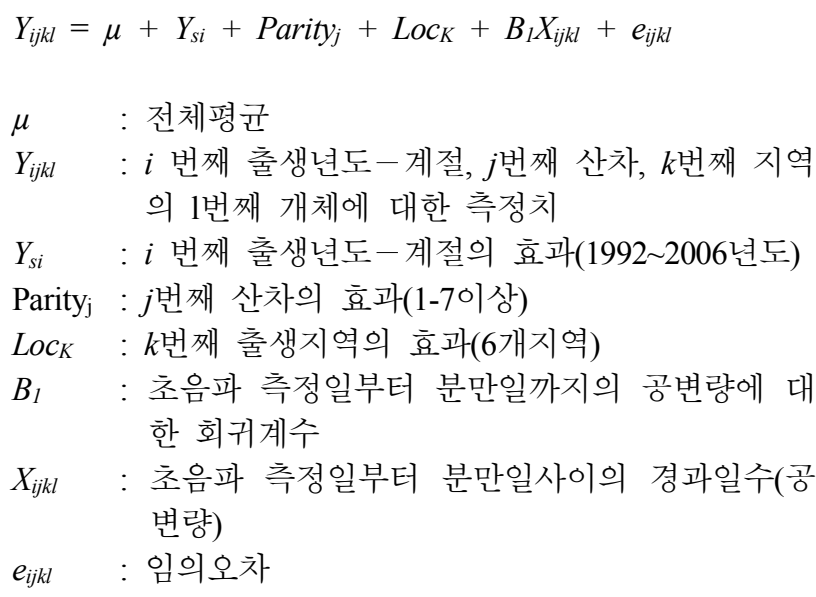

형질들간의 상관관계를 알아보기 위하여 아래와 같은
공식으로 표현형 상관계수를 추정하였으며, 선형모형에 포함한 제반 요인의 효과를 제거한 후 각 형질들간의 상 관관계를 규명하기 위하여 각 형질별로 잔차를 구한 후 잔차상관계수를 추정하였다.

$$
\mathrm{r}_{\mathrm{x}, \mathrm{y}}=\operatorname{cov}(\mathrm{X}, \mathrm{Y}) / \sigma_{\mathrm{X}} \sigma_{\mathrm{Y}}
$$

\section{III. 결과 및 고찰}

\section{1. 분산분석 및 회귀계수}

Table 3은 산육형질별 출생년도-계절, 산차, 지역, 측정 일-분만일까지의 mean square과 회귀계수를 나타낸 것이 다. 분산분석의 경우에서는 산육형질별 유의적 $(\mathrm{p}<0.01$, $\mathrm{p}<0.05)$ 인 차이를 나타냈으며, 지역별 및 산차별 산육특성 에서 각각 가장 크고 작은 수치를 나타냈다. 또한, 회귀모 수에서 절편의 값은 산육형질별 $50.04 \pm 0.30,3.02 \pm 0.07$, $1.71 \pm 0.03,5.73 \pm 0.12$ 으로 분석되었고, 계수는 증가하는 경향의 정 $(+)$ 의 관계로 나타났다.

\section{2. 번식우의 산차별 산육특성 비교}

초음파 진단장치를 이용하여 조사한 산차별 전체 번식 우의 산육특성 관련 형질들을 비교분석한 결과는 Table 4 이다. 위의 결과에서는 등지방두께 (BFTU)를 제외한 모든 형질에서 유의적 $(\mathrm{p}<0.01, \mathrm{p}<0.05)$ 인 차이를 보였으며, 산차 가 많아질수록 배최장근단면적 (LMAU), 등지방두께 (BFTU), 근내지방도 $(\mathrm{MSU})$, 둔근지방두께 $(\mathrm{P} 8 \mathrm{FTU})$ 는 6산까지는 대 체적으로 증가하다가, 7산차 이후에는 감소하는 경향을 나타내었다. 이는 Harada (1996)의 보고에서와 같이 초음파 진단장치를 이용하여 갈모화우의 산차에 따른 산육특성 형질에 대한 연구결과 3 5산차에서 최고치에 이른다고 보 고한 것과 유사하였다. 또한, 구 (2007)의 연구결과와 같이 전체적으로 47 개월령에서 산육형질이 다른 개월령에 비해 유의적 $(\mathrm{p}<0.05)$ 으로 높게 추정되었다는 것과 위의 결과가 일치하는 것을 나타낼 수 있었다.

송(2007)의 보고에서는 한우 번식우의 5산차까지의 등지 방두께(BFTU)는 산차가 높아질수록 두꺼워지는 경향을 보

Table 2. Statistics of live carcass traits measured by ultrasound in Hanwoo cow

\begin{tabular}{lccccc}
\hline \multicolumn{1}{c}{ Source } & Mean & $\mathrm{SD}^{5)}$ & $\mathrm{CV}^{6}$ & Min & Max \\
\hline \hline LMAU $\left(\mathrm{cm}^{2}\right)^{1)}$ & 51.21 & 9.56 & 18.67 & 30.20 & 86.60 \\
BFTU (mm) ${ }^{2)}$ & 3.37 & 2.32 & 68.84 & 1.00 & 11.00 \\
MSU (No.) ${ }^{3)}$ & 1.82 & 0.97 & 53.29 & 1.00 & 5.00 \\
P8 FTU (mm) & 6.03 & 3.76 & 62.35 & 1.00 & 17.00 \\
\hline
\end{tabular}

\footnotetext{
${ }^{1)}$ LMAU : Longissimus Muscle Area by Ultrasound $\left(\mathrm{cm}^{2}\right),{ }^{2)}$ BFTU : Back Fat Thickness by Ultrasound (mm)

${ }^{3)}$ MSU : Marbling Score by Ultrasound (No.), $\quad{ }^{4)}$ P8 FTU : P8 Point Fat Thickness by Ultrasound (mm)

${ }^{5)} \mathrm{SD}$ : Standard Deviation,

${ }^{6} \mathrm{CV}$ : Coefficient of Variation (\%)
} 
Table 3. Mean squares and regression parameters of live carcass traits in cow

\begin{tabular}{|c|c|c|c|c|c|}
\hline \multirow{2}{*}{ Source } & \multirow{2}{*}{$\mathrm{DF}^{5)}$} & \multicolumn{4}{|c|}{ Mean squares } \\
\hline & & $\operatorname{LMAU}\left(\mathrm{cm}^{2}\right)^{1)}$ & $\mathrm{BFTU}(\mathrm{mm})^{2)}$ & MSU(No.) $)^{3)}$ & P8 FTU $(\mathrm{mm})^{4)}$ \\
\hline Year-season & 24 & $193.78 * *$ & $16.43 * *$ & $2.03 * *$ & $40.71 * *$ \\
\hline Parity & 6 & $178.99 *$ & 6.73 & $2.13 *$ & $22.75^{*}$ \\
\hline Region & 5 & $815.10^{* *}$ & $91.60 * *$ & $7.55^{* *}$ & $482.75^{* *}$ \\
\hline $\mathrm{Pd}^{6)}$ & 1 & $601.11 * *$ & 10.05 & 2.36 & 35.00 \\
\hline Regression & Intercept & $50.04(0.30)^{7)}$ & $3.02(0.07)$ & $1.71(0.03)$ & $5.73(0.12)$ \\
\hline Parameters & Coefficient & $0.0081(0.0012)$ & $0.0024(0.0003)$ & $0.0007(0.0001)$ & $0.0033(0.0005)$ \\
\hline
\end{tabular}

${ }^{1)}$ LMAU : Longissimus Muscle Area by Ultrasound $\left(\mathrm{cm}^{2}\right),{ }^{2)}$ BFTU : Back Fat Thickness by Ultrasound (mm)

${ }^{3)}$ MSU : Marbling Score by Ultrasound (No.), $\quad{ }^{4)}$ P8 FTU : P8 FTU Fat Thickness by Ultrasound (mm)

${ }^{5)} \mathrm{DF}$ : Degree of freedom,

${ }^{7)}$ ( ) : Standard error, ** $\mathrm{p}<0.01, * \mathrm{p}<0.05$

6) $\mathrm{Pd}$ : Covariate of age from measure day to calving day

Table 4. Least square means and standard error of live carcass traits by parity in cow

\begin{tabular}{cccccc}
\hline Parity & $\begin{array}{c}\text { Number of } \\
\text { animal }\end{array}$ & LMAU $\left(\mathrm{cm}^{2}\right)^{1)}$ & BFTU(mm $)^{2)}$ & MSU(No. $)^{3)}$ & P8 FTU(mm $)^{4)}$ \\
\hline \hline & & $* *$ & ns & $* *$ & $6.54 \pm 0.55$ \\
1 & 360 & $54.56 \pm 1.48$ & $4.10 \pm 0.35$ & $2.33 \pm 0.15$ & $7.18 \pm 0.48$ \\
3 & 291 & $55.05 \pm 1.27$ & $4.34 \pm 0.30$ & $2.40 \pm 0.13$ & $6.29 \pm 0.48$ \\
4 & 173 & $53.31 \pm 1.27$ & $3.97 \pm 0.30$ & $2.17 \pm 0.13$ & $6.23 \pm 0.49$ \\
5 & 96 & $53.52 \pm 1.31$ & $3.62 \pm 0.31$ & $2.25 \pm 0.13$ & $6.58 \pm 0.62$ \\
6 & 50 & $50.51 \pm 1.66$ & $3.43 \pm 0.39$ & $2.06 \pm 0.17$ & $7.92 \pm 0.64$ \\
$\geq 7$ & 45 & $53.40 \pm 1.70$ & $4.36 \pm 0.40$ & $1.87 \pm 0.17$ & $1.63 \pm 0.16$ \\
\hline Average & 65 & $48.46 \pm 1.53$ & $4.04 \pm 0.36$ & $2.10 \pm 0.27$ & $6.36 \pm 0.57$ \\
\hline
\end{tabular}

1) LMAU : Longissimus Muscle Area by Ultrasound $\left(\mathrm{cm}^{2}\right), \quad{ }^{2)}$ BFTU : Back Fat Thickness by Ultrasound (mm)

3) MSU : Marbling Score by Ultrasound (No.),

** $\mathrm{p}<0.01, * \mathrm{p}<0.05, \mathrm{~ns}:$ not significant.

였다고 하였으나 위의 시험에서 측정한 결과 2 산 이후에 서는 점차 감소하다가 6산차에서 증가 후 다시 감소하는 것으로 분석되었으며, 이는 6산차의 측정두수의 차이로 해석된다.

또한, 한우 암소의 생리적 산육특성 관련 형질들의 발 달이 3산차에서 완성되는 것으로 분석하였으나, 위의 실 험에서는 2산차에서 생리적으로 산육능력이 우수한 것으 로 나타났다.

Bailey 등 (1991)은 Bos taurus와 Bos indicus의 F1을 Bos taurus와 교잡한 미경산우와 초산우를 대상으로 등지방, 배 최장근단면적 및 근내지방도 등을 비교한 결과 배최장근
단면적과 근내지방도에 대한 산차의 영향은 없다고 보고 하였으나, 본 시험에서는 산차가 배최장근단면적, 근내지 방도 및 둔근지방두께에 유의적 $(\mathrm{p}<0.01, \mathrm{p}<0.05)$ 인 차이를 나타낸 것과 상이한 결과를 나타냈는데 이는 사육환경 및 품종과 사양관리의 차이에서 비롯된 것으로 판단된다.

\section{3. 지역에 따른 산육특성}

초음파 진단장치를 이용한 지역별 한우 암소의 산육특 성은 Table 5에 나타내었다. 위의 결과에서의 각 지역별로 고도의 유의적 $(\mathrm{p}<0.01)$ 인 차이를 나타냈으며, 산육특성은 
Ha et al. ; Variation of Hanwoo Cows Measured by Real-time Ultrasound

Table 5. Least square means and standard error of live carcass traits by region in cow

\begin{tabular}{cccccc}
\hline Region & $\begin{array}{c}\text { Number of } \\
\text { animal }\end{array}$ & LMAU $\left(\mathrm{cm}^{2}\right)^{1)}$ & BFTU(mm) & MSU(No.) $)^{3)}$ & P8 FTU(mm) \\
\hline \hline Chuncheon & 552 & $* *$ & $* *$ & $* *$ & $7.87 \pm 0.30$ \\
Cheorwon & 192 & $51.98 \pm 1.09$ & $3.66 \pm 0.25$ & $1.93 \pm 0.11$ & $6.77 \pm 0.40$ \\
Hwacheon & 72 & $59.11 \pm 1.45$ & $5.76 \pm 0.34$ & $2.64 \pm 0.15$ & $10.46 \pm 0.54$ \\
Yanggu & 192 & $49.41 \pm 0.94$ & $2.92 \pm 0.22$ & $1.72 \pm 0.09$ & $3.53 \pm 0.35$ \\
Inje & 185 & $50.42 \pm 1.01$ & $4.32 \pm 0.24$ & $2.07 \pm 0.10$ & $6.86 \pm 0.38$ \\
Hoengseong & 193 & $52.27 \pm 1.00$ & $2.96 \pm 0.23$ & $2.21 \pm 0.10$ & $5.75 \pm 0.37$ \\
\hline Average & 1,386 & $52.69 \pm 3.40$ & $3.98 \pm 1.06$ & $2.10 \pm 0.31$ & $6.87 \pm 2.29$ \\
\hline
\end{tabular}

\footnotetext{
1) LMAU : Longissimus Muscle Area by Ultrasound $\left(\mathrm{cm}^{2}\right)$, ${ }^{2)}$ BFTU : Back Fat Thickness by Ultrasound (mm)

3) MSU : Marbling Score by Ultrasound (No.), $\quad{ }^{4)}$ P8 FTU : P8 FTU Fat Thickness by Ultrasound (mm)

** $p<0.01$
}

각 지역마다의 특징을 알아볼 수 있었다.

화천지역에서는 배최장근단면적 (LMAU) $59.11 \mathrm{~cm}^{2}$, 근내 지방도(MSU) 2.64로 가장 높은 산육형질을 나타냈으며, 양구지역은 등지방두께 (BFTU) $2.92 \mathrm{~mm}$, 둔근지방두께 (P8 FTU) $3.53 \mathrm{~mm}$ 로 가장 낮은 수치를 보였다. 그 밖에 춘천 지역에서는 근내지방도를 제외한 모든 산육형질, 인제지 역에서는 등지방두께 (BFTU), 횡성지역에서는 근내지방도 (MSU)가 산육형질 중 평균을 상회하는 것으로 분석되 었다.

송(2007)의 보고에서는 축산과학원 한우시험장의 한우 번식우 629두의 초음파 측정결과 배최장근단면적 (LMAU) 은 $51.00 \mathrm{~cm}^{2}$, 등지방두께 (BFTU) $3.89 \mathrm{~mm}$, 근내지방도 (MSU) 4.12, 둔근지방두께 (P8 FTU) $8.66 \mathrm{~mm}$ 의 결과로 분 석하여 위 시험지역의 평균과 유사한 경향을 보였다.

\section{4. 출생년도와 계절에 따른 산육특성}

Table 6은 암소의 출생년도 및 계절에 따른 초음파 산 육형질의 변화 추세를 나타낸 것이다. 측정두수는 2005년 봄에 태어난 두수가 263 두로 가장 많은 분포를 나타내었 으며, 1993년 봄에 태어난 두수가 2두로 가장 적은 비율 을 나타내었다.

출생년도와 계절에 따른 산육형질에서 우수한 개체들은 대부분 가을철 2000년에 태어난 개체들의 배최장근단면적 $(\mathrm{LMAU})$ 과 근내지방도 $(\mathrm{MSU})$ 가 각각 $60.89 \pm 3.80 \mathrm{~cm}^{2}, 3.33$ \pm 0.40 이었으며, 2005년생 등지방두께 (BFTU)가 $2.04 \pm$ $0.42 \mathrm{~mm}$, 2006년생 둔근지방두께 (P8 FTU)가 $3.85 \pm 2.04$ $\mathrm{mm}$ 로 분석되었다.

반면, 산육형질이 가장 불량한 개체들은 배최장근단면
적 (LMAU)과 근내지방도 $(\mathrm{MSU})$ 에서 2006년 봄철의 41.76 $\pm 2.64 \mathrm{~cm}^{2}, 0.91 \pm 0.27$ 이었으며, 등지방두께 $(\mathrm{BFTU})$ 와 둔근 지방두께 $(\mathrm{P} 8 \mathrm{FTU})$ 에서는 각각 $7.26 \pm 0.90 \mathrm{~mm}, 12.05 \pm 1.53$ $\mathrm{mm}$ 로 2000 년도 가을철 태생에서 나타났다.

위의 결과에서와 같이 대체적으로 가을철에 태어난 개 체들의 산육특성이 큰 것으로 나타났으며, 이는 하 등 (2008)의 한우 거세우의 계절별 행동특성 중 가을철에 유 의적 $(\mathrm{p}<0.05)$ 으로 높은 사료섭취시간을 나타냈다는 보고 와 연관성이 있을 것으로 판단된다. 또한, 배최장근단면적 $(\mathrm{LMAU})$ 과 근내지방도 $(\mathrm{MSU})$ 의 우수 혹은 불량의 패턴이 어느 정도 동일하게 나타난 것을 분석할 수 있었으며, 불 량한 개체들 중의 등지방두께 (BFTU)와 둔근지방두께(P8 $\mathrm{FTU})$ 는 두수의 부족으로 정확한 분석이 되었다고 판단하 기는 어렵다.

최 (2007)의 보고에서는 1990년생부터 2005년생까지의 홍천늘푸름한우 1,117 두의 가임암소 산육형질 평균을 살 펴보면 배최장근단면적 (LMAU)는 $53.4 \mathrm{~cm}^{2}$, 등지방두께 $(\mathrm{BFTU})$ 는 $3.3 \mathrm{~mm}$, 근내지방도 $(\mathrm{MSU}) 1.7$ 로 위의 분석치와 대체적으로 유사한 것으로 판단된다.

\section{5. 산육특성 관련 형질간의 상관관계}

산육특성 관련 형질간의 잔차 및 표현형 상관관계는 Table 7에 나타내었다. 대부분의 형질은 상호간 상관이 어 느 정도 높은 것으로 분석되었으며, 유의적 $(\mathrm{p}<0.01)$ 인 차 이도 나타냈다. 둔근지방두께와 등지방두께의 상관은 상 관계수가 가장 높았고, 반대로 배최장근단면적과 둔근지 방두께의 잔차 상관계수, 등지방두께와 근내지방도의 표 현형 상관계수가 가장 낮았다. 
Table 6. Least square means and standard error of live carcass traits by year-season

\begin{tabular}{|c|c|c|c|c|c|c|}
\hline \multicolumn{2}{|c|}{ Year-season } & $\begin{array}{c}\text { Number of } \\
\text { animal }\end{array}$ & $\operatorname{LMAU}\left(\mathrm{cm}^{2}\right)^{1)}$ & $\operatorname{BFTU}(\mathrm{mm})^{2)}$ & MSU(No.) $)^{3)}$ & P8 FTU $(\mathrm{mm})^{4)}$ \\
\hline 1992 & Spring & 4 & $44.33 \pm 5.49$ & $2.48 \pm 1.30$ & $2.35 \pm 0.57$ & $6.02 \pm 2.02$ \\
\hline 1993 & Spring & 2 & $56.94 \pm 6.75$ & $2.95 \pm 1.60$ & $2.33 \pm 0.70$ & $4.78 \pm 2.49$ \\
\hline 1995 & Spring & 3 & $53.21 \pm 5.45$ & $5.50 \pm 1.30$ & $2.71 \pm 0.57$ & $8.22 \pm 2.01$ \\
\hline \multirow{2}{*}{1996} & Spring & 18 & $53.09 \pm 2.48$ & $3.84 \pm 0.59$ & $2.05 \pm 0.26$ & $6.39 \pm 0.92$ \\
\hline & Autumn & 3 & $57.64 \pm 5.47$ & $3.06 \pm 1.30$ & $2.58 \pm 0.57$ & $7.25 \pm 2.01$ \\
\hline \multirow{2}{*}{1997} & Spring & 38 & $57.34 \pm 1.69$ & $5.11 \pm 0.41$ & $2.49 \pm 0.17$ & $7.86 \pm 0.64$ \\
\hline & Autumn & 4 & $49.86 \pm 4.75$ & $2.52 \pm 1.13$ & $1.76 \pm 0.50$ & $4.72 \pm 1.75$ \\
\hline \multirow{2}{*}{1998} & Spring & 22 & $58.12 \pm 2.13$ & $5.01 \pm 0.51$ & $2.66 \pm 0.22$ & $7.62 \pm 0.84$ \\
\hline & Autumn & 6 & $57.59 \pm 4.00$ & $4.91 \pm 0.95$ & $2.62 \pm 0.42$ & $6.84 \pm 1.48$ \\
\hline \multirow{2}{*}{1999} & Spring & 32 & $51.58 \pm 1.80$ & $4.00 \pm 0.42$ & $2.07 \pm 0.18$ & $6.22 \pm 0.68$ \\
\hline & Autumn & 14 & $54.62 \pm 2.58$ & $4.10 \pm 0.61$ & $2.04 \pm 0.27$ & $7.16 \pm 0.95$ \\
\hline \multirow{2}{*}{2000} & Spring & 37 & $57.85 \pm 1.60$ & $5.94 \pm 0.38$ & $2.51 \pm 0.16$ & $9.46 \pm 0.63$ \\
\hline & Autumn & 6 & $60.89 \pm 3.80$ & $7.26 \pm 0.90$ & $3.33 \pm 0.40$ & $12.05 \pm 1.53$ \\
\hline \multirow{2}{*}{2001} & Spring & 35 & $55.92 \pm 1.65$ & $5.05 \pm 0.39$ & $2.24 \pm 0.17$ & $7.89 \pm 0.62$ \\
\hline & Autumn & 12 & $52.16 \pm 2.74$ & $5.10 \pm 0.65$ & $2.13 \pm 0.28$ & $8.53 \pm 1.01$ \\
\hline \multirow{2}{*}{2002} & Spring & 85 & $54.33 \pm 1.19$ & $4.70 \pm 0.28$ & $2.09 \pm 0.12$ & $8.69 \pm 0.45$ \\
\hline & Autumn & 26 & $49.86 \pm 2.01$ & $3.57 \pm 0.49$ & $2.03 \pm 0.21$ & $8.01 \pm 0.75$ \\
\hline \multirow{2}{*}{2003} & Spring & 134 & $52.75 \pm 1.16$ & $3.95 \pm 0.27$ & $2.01 \pm 0.12$ & $7.66 \pm 0.43$ \\
\hline & Autumn & 62 & $49.77 \pm 1.46$ & $3.57 \pm 0.35$ & $1.81 \pm 0.15$ & $6.56 \pm 0.55$ \\
\hline \multirow{2}{*}{2004} & Spring & 157 & $50.29 \pm 1.23$ & $3.26 \pm 0.29$ & $1.60 \pm 0.12$ & $5.79 \pm 0.46$ \\
\hline & Autumn & 87 & $50.70 \pm 1.41$ & $3.33 \pm 0.33$ & $1.68 \pm 0.14$ & $6.30 \pm 0.53$ \\
\hline \multirow{2}{*}{2005} & Spring & 263 & $50.14 \pm 1.44$ & $3.01 \pm 0.34$ & $1.62 \pm 0.15$ & $5.91 \pm 0.54$ \\
\hline & Autumn & 94 & $48.10 \pm 1.77$ & $2.04 \pm 0.42$ & $1.37 \pm 0.18$ & $3.92 \pm 0.66$ \\
\hline \multirow{2}{*}{2006} & Spring & 207 & $41.76 \pm 2.64$ & $2.18 \pm 0.63$ & $0.91 \pm 0.27$ & $4.08 \pm 0.98$ \\
\hline & Autumn & 35 & $48.40 \pm 5.52$ & $3.04 \pm 1.31$ & $1.53 \pm 0.58$ & $3.85 \pm 2.04$ \\
\hline \multicolumn{2}{|c|}{ Average } & 1,386 & $52.22 \pm 4.72$ & $3.94 \pm 1.57$ & $2.10 \pm 0.35$ & $8.93 \pm 4.11$ \\
\hline
\end{tabular}

\footnotetext{
1) LMAU : Longissimus Muscle Area by Ultrasound $\left(\mathrm{cm}^{2}\right), \quad{ }^{2)}$ BFTU : Back Fat Thickness by Ultrasound (mm)

3) MSU : Marbling Score by Ultrasound (No.),

4) P8 FTU : P8 FTU Fat Thickness by Ultrasound (mm)

** $\mathrm{p}<0.01$
}

Odhiambo (2005)는 2 14세의 암소 135두를 대상으로 연 께의 상관계수는 0.83 을 나타내어 다른 형질간의 상관에 령, 체중, 갈비지방두께, 둔근피하지방두께 사이의 상관관 비해 가장 높게 나타났는데, 본 시험에서도 등지방두께와 계를 보고하였다. 그 중 갈비지방두께와 둔근피하지방두 둔근피하지방두께의 상관계수가 다른 산육특성 형질의 상 
Ha et al. ; Variation of Hanwoo Cows Measured by Real-time Ultrasound

Table 7. Residual and pearson correlation coefficient among live carcass traits of cow

\begin{tabular}{ccccc}
\hline & LMAU $\left(\mathrm{cm}^{2}\right)^{1)}$ & BFTU $(\mathrm{mm})^{2)}$ & MSU(No. $)^{3)}$ & P8 FTU $(\mathrm{mm})^{4)}$ \\
\hline \hline LMAU $\left(\mathrm{cm}^{2}\right)^{1)}$ & - & $0.69^{* *}$ & $0.69^{* *}$ & $0.69^{* *}$ \\
BFTU(mm) $)^{2)}$ & $0.57^{* *}$ & - & $0.56^{* *}$ & $0.91^{* *}$ \\
MSU(No. $)^{3)}$ & $0.57^{* *}$ & $0.63 * *$ & - & $0.77^{* *}$ \\
P8 FTU(mm) & $0.51^{* *}$ & $0.70^{* *}$ & $0.53^{* *}$ & - \\
\hline
\end{tabular}

\footnotetext{
1) LMAU : Longissimus Muscle Area by Ultrasound $\left(\mathrm{cm}^{2}\right), \quad{ }^{2)}$ BFTU : Back Fat Thickness by Ultrasound (mm)

3) MSU : Marbling Score by Ultrasound (No.), $\quad{ }^{4)}$ P8 FTU : P8 FTU Fat Thickness by Ultrasound (mm)

Below diagonal : residual correlation, upper diagonal : pearson correlation, $* * \mathrm{p}<0.01$
}

관보다 월등히 높게 나타나 일치하는 경향을 보였다.

또한, Ozutsumi (1988)은 초음파 B Scope를 이용한 등지 방두께와 배최장근 단면적의 상관계수가 0.79 이었고, 구 (2007)는 근내지방도와 배최장근단면적 그리고 근내지방도 와 등지방두께의 상관계수가 각각 $0.42,0.36$ 으로 보고하 여 위 시험과는 차이를 보였는데 이는 사육환경, 임신, 사 양관리, 사료, 품종, 성별 등의 차이에 의해 비롯되어졌다 고 판단된다.

\section{IV. 요 약}

본 시험은 초음파 진단장치를 이용한 한우 번식우의 산 차 및 지역별 산육특성에 관한 연구에 대하여 알아보고자 실시하였다. 강원도 6 개시·군 한우 번식우 1,386 두를 공 시하여 초음파 진단장치(HS-2000, Japan)를 이용하여 배최 장근단면적(LMAU; Longissimus Muscle Area Ultrasound), 등지방두께(BFTU; Back Fat Thickness Ultrasound), 근내지 방도(MSU; Marbling Score Ultrasound), 둔근지방두께(P8 FTU; P8 Fat Thickness Ultrasound)를 측정하였다. 성적 조 사 및 자료의 조정 후 각 한우의 출생년도-계절, 지역 및 산차별 산육특성을 비교 - 분석한 결과는 다음과 같다. 산차별 산육특성을 비교했을 때 산차가 증가할수록 산육 형질은 6산까지 증가하다가 7산차 이후에는 감소하는 경 향을 나타냈다. 또한, 지역별 산육특성을 비교하면 모든 지역에서 고도의 유의적 $(\mathrm{p}<0.01)$ 인 차이를 보였으며 화천 지역의 암소에서 배최장근단면적과 근내지방도가 가장 높 은 수치를 나타냈으며, 양구지역의 경우 등지방두께, 둔근 지방두께가 가장 낮은 수치를 보였다. 출생년도와 계절에 따른 산육형질에서는 2000년 가을철 태생의 개체의 배최 장근단면적과 근내지방도, 2005년과 2006년 가을철 태생 에서 각각 등지방두께 및 둔근지방두께가 우수한 것으로 분석되었다. 산육특성관련 형질간의 상관관계에서는 상호 간 상관이 어느 정도 높은 것으로 나타났으며, 등지방두 께와 둔근지방두께의 상관계수가 가장 높았고, 반대로 배 최장근단면적과 둔근지방두께의 상관계수가 가장 낮았다.
이상의 결과를 종합하여 볼 때, 6산차까지의 산육형질 이 우수한 것으로 분석되었고, 지역 차이에 따른 산육형 질의 특징이 나타났으며, 등지방두께와 둔근지방두께의 상관관계가 가장 높은 것으로 분석되어, 본 시험결과는 앞으로 한우 번식우 개량 및 사양관리에 적절하게 이용할 수 있을 것으로 판단된다.

$$
\mathrm{V} \text {. 사 사 }
$$

본 시험은 농촌진흥청 특화작목연구개발 (과제번호: 20070101070002)에 의해 이루어 졌기에 이에 감사를 드립 니다.

\section{VI. 인 용 문 헌}

1. Bailey, C. M., Reid, C. R., Ringkob, T. P., Koh, Y. O. and Foote, W. D. 1991. Nullipatous versus primiparous crossbred females for beef. J. Anim. Sci. 69:1403-1408.

2. Harada, H. 1996. Application of ultrasound for Estimating Carcass Traits of Beef cattle and Pigs. Animla Science and Technology. Academic Journal. 67(7):651-666.

3. Odhiambo, J. F. 2005. MANAGEMENT OF THE SUCKLED POST PARTUM BEEF COWS: PASTURE BASED WEANING SYSTEM. West Virginia University.

4. Ozutsumi, K., Chikuni, K., Koishikawa, T., Kato, S., Oto, K., Kovayashi, M., Ebata, T., Tamada Y. and Yoshitake, M. 1988. Improved method for estimating M. Longissimus thoracis fat and area on live beefcattle with a color scanning scope. Jpn. J. Zootech. Sci. 59(11):916-921.

5. 권응기, 조영무, 최연호, 박병기, 정학재, 최낙진, 안병석, 김 종복. 2006. 한우 암소의 유전능력과 산차에 따른 분만 전 · 후 체중, Body Condition Score 및 혈중 대사물질의 변화. 한 국동물자원과학회지. 48(6):881-888.

6. 구양모. 2007. 한우 번식우의 초음파 및 능력검정 성적에 대 한 유전상관 및 유전모수 추정에 관한 연구. 경상대학교. 석 
사학위논문.

7. 배정규. 2003. 초음파를 이용한 한우 둔근지방층의 생체측정 에 관한 연구. 동아대학교. 석사학위논문.

8. 송창수. 2007. 초음파 진단장치를 이용한 한우 번식우의 산 차별 산육특성에 관한 연구. 강원대학교. 석사학위논문.

9. 전기준, 최재관, 이명식, 정영훈, 정호영, 이종경, 임석기, 이 창우, 박정준, 나기준. 2003. 한우에서 혈중 호르몬 및 대사 물질 농도와 성장 및 도체형질에 대한 표현형 상관에 관한
연구. 한국수정란이식학회지. 18:203-213.

10. 최현호. 2007. 초음파를 이용한 한우 우량암소 선발 및 개량 방안. 한경대학교. 석사학위논문.

11. 하재정, 이용준, 조재희, 장원진, 김연욱, Li shaogang, 송영한. 2008. 한우 거세우의 계절 및 군 두수별 행동 특성. 한국축 산시설환경학회지. 14(1):9-14

(접수일자 : 2009. 1. 20. / 수정일자 : 2009. 5. 25. / 채택일자 : 2009. 5. 28.) 